\title{
Escola de
}
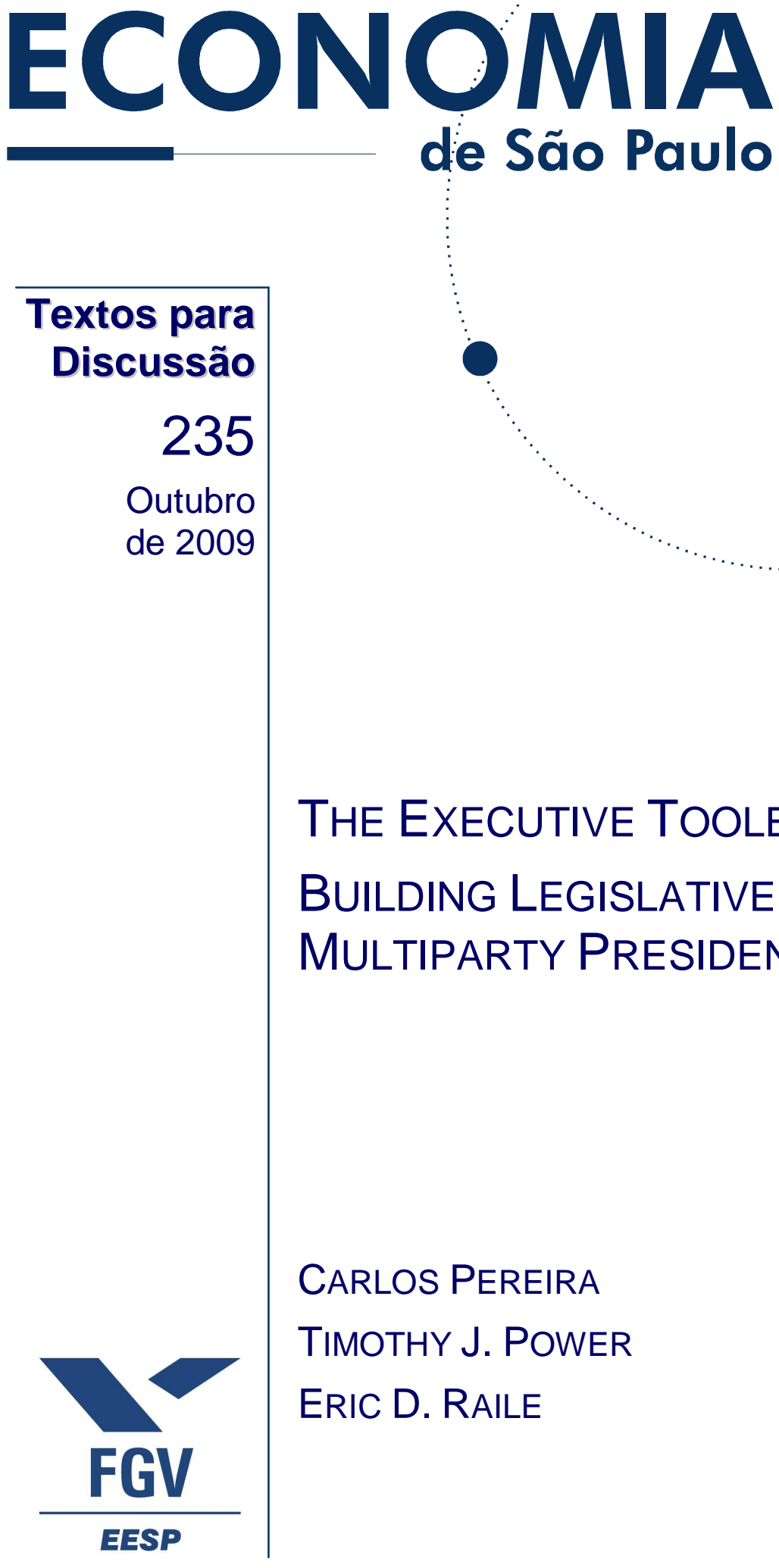
Os artigos dos Textos para Discussão da Escola de Economia de São Paulo da Fundação Getulio

Vargas são de inteira responsabilidade dos autores e não refletem necessariamente a opinião da FGV-EESP. É permitida a reprodução total ou parcial dos artigos, desde que creditada a fonte.

Escola de Economia de São Paulo da Fundação Getulio Vargas FGV-EESP www.fgvsp.br/economia

\section{TEXTO PARA DISCUSSÃO 235 • OUTUBRO DE $2009 \cdot 1$}


The Executive Toolbox:

Building Legislative Support in a Multiparty Presidential Regime

\author{
Carlos Pereira \\ Michigan State University \\ pereir12@msu.edu \\ Timothy J. Power \\ University of Oxford \\ timothy.power@brazil.ox.ac.uk \\ Eric D. Raile \\ North Dakota State University \\ Eric.Raile@ndsu.edu
}

MANUSCRIPT (15 May 2009)

\begin{abstract}
How do presidents win legislative support under conditions of extreme multipartism? Comparative presidential research has offered two parallel answers, one relying on distributive politics and the other claiming that legislative success is a function of coalition formation. We merge these insights in an integrated approach to executive-legislative relations, also adding contextual factors related to dynamism and bargaining conditions. We find that the two presidential "tools" - pork and coalition goods - are substitutable resources, with pork functioning as a fine-tuning instrument that interacts reciprocally with legislative support. Pork expenditures also depend upon a president's bargaining leverage and the distribution of legislative seats.
\end{abstract}




\section{Introduction}

In the early 1990s, the critique of presidentialism advanced by Linz (1994) and others was widely influential, and the coexistence of presidentialism with multipartism was viewed as a particularly "difficult combination." Multipartism was expected to exacerbate the "perils of presidentialism" by increasing the probability of deadlock in executive-legislative relations, by promoting ideological polarization, and by making interparty coalition building difficult to achieve (Mainwaring 1993; Stepan and Skach 1993). The best chances for the survival of presidential democracies, it was argued, lay in the adoption of a two-party format, which would reduce polarization, obviate coalitional politics, and promote governability. Yet multiparty presidentialism was here to stay. This unanticipated outcome has raised questions about how presidents have managed this "difficult combination."

That multiparty presidential democracy is sustainable is now beyond dispute, yet we still lack a comprehensive explanation of why this is the case. The aim of this paper is to extend and refine recent models of multiparty presidentialism by adopting a wider perspective on the "tools" available to presidents who face fragmented legislatures. Institutional approaches to these questions have produced promising evidence. As Shugart and Carey (1992) anticipated, institutions that help lubricate the machinery of government often appear when constitution writers have reasons to believe that governability will be difficult in the future. As a result, the structure of multiparty presidentialism does not preclude the formation of coalition governments. Quite to the contrary, as Cheibub $(2007,50)$ observes, "There is a range of possible scenarios in presidential systems where presidents will make coalition offers and parties will find it in their interest to accept them." Coalition presidencies have in fact proven unexpectedly functional and 
durable (Cheibub, Przeworski, and Saiegh 2004) while becoming the modal form of democracy in Latin America.

In what follows, we first note problems with applying theoretical models designed primarily for parliamentary regimes directly to separation-of-powers regimes. We then build on extant research concerning legislative support in multiparty presidential systems. In so doing, we integrate two separate institutional arguments about how presidents solve the "governability equation" under multipartism. The first of these arguments holds that presidents win support via distributive politics, particularly through the targeted transfer of pork to legislators (e.g., Ames 2001). The second of these arguments (familiar to students of parliamentary government) claims that presidents secure legislative support through the judicious allocation of cabinet portfolios and other such "coalition goods" (e.g., Amorim Neto 2002). Beyond integrating these two approaches, we also complete the picture by adding considerations of dynamism and context. After a brief overview of the Brazilian case, we examine differences in executive strategy among the last three Brazilian presidents. Empirical analysis supports a view of pork and coalition goods as substitutable resources, with pork functioning as a fine-tuning tool that interacts reciprocally with legislative support. Pork expenditures also depend upon a president's bargaining leverage and the distribution of legislative seats.

\section{Coalition Presidents and Policymaking}

Models regarding coalition formation in parliamentary regimes double as explanations for legislative support of executive policy positions. These models typically rely, though often implicitly, on assumptions taken straight from the theory of responsible party government: Strong, disciplined parties provide legislative support in exchange for spots in the formal pro- 
government coalition and cabinet seats. Some models focus almost exclusively on the relative sizes of parties in the legislature, with either purely proportional cabinet payoffs for parties in the government coalition (e.g., Morelli 1999; Montero 2003; Morelli and Montero 2003) or basically proportional payoffs with a bonus for the formateur, or coalition-proposing, party (Baron and Ferejohn 1987, 1989; Ansolabehere et al. 2005; Snyder, Ting, and Ansolabehere 2005).

Other models have attempted to explain which parties in particular will be included in the government coalition (for excellent summaries of this line of research see Laver 1998; Martin and Stevenson 2001). ${ }^{1}$ By adding consideration of party ideology to party size, these models at least implicitly acknowledge that support may come at lower cost from some parties as compared to others. Often, a rational formateur attempts to assemble a coalition just large enough to pass legislation but with maximum ideological agreement. The idea behind a "minimal connected winning coalition" (Axelrod 1970) or a minimal winning coalition with the smallest possible ideological range (de Swaan 1973) is that such a coalition provides for legislative success while also minimizing intra-coalitional transaction costs. Veto players theory (Tsebelis 2002) has also incorporated this logic concerning ideology. A larger number of veto players typically makes policy change from the status quo more difficult as preference overlap shrinks. Panel 1A of Figure 1 coarsely summarizes the assumptions built into traditional parliamentary models. Quite simply, disciplined political parties provide legislative support in return for their inclusion in the government.

\footnotetext{
1 While Martin and Stevenson (2001) also discuss various neo-institutionalist theories of coalition formation, such theories have less bearing on the issue of legislative support than do models utilizing party size and ideology.
} 
[Figure 1 about here]

These explanations of coalition formation and policymaking, based as they are on the constellation of Western European parliamentary regimes, prove less than ideal when applied to multiparty presidential regimes. The separation of powers makes the emergence of anything resembling responsible party government unlikely. Here, the formateur (the president) must reach across institutional barriers meant to complicate cooperation. Electoral systems that reward particularistic benefits (e.g., pork) for local districts, like the single-member district rules in the U.S. or open-list proportional representation systems in federal regimes like Brazil, further erode the influence of party leadership and can reduce the importance of ideology.

What happens, then, if parties are weaker and less disciplined and ideological preferences are not necessarily the primary determinant of voting decisions? In some presidential regimes, the lack of party loyalty and discipline means that a minimal "winning" coalition may not be enough to win consistently over time. Minimal winning coalitions are also suspect in that they give inordinate power to smaller coalition parties, who can become hostage takers. As a consequence, a formateur may find it cheaper to assemble supermajorities in which no single partner can envision itself as the leverage point (Groseclose and Snyder 1996). In response to such concerns, two separate approaches have emerged to explain how the executive boosts voting discipline and buys additional votes in order to cobble together winning coalitions in multiparty, coalition-based presidential systems.

The first approach recognizes that the success of multiparty presidentialism, with its fixed terms and lack of confidence votes, largely depends on what happens on a day-to-day basis during the executive's constitutional term of office. The executive uses particularistic benefits on an ongoing basis to overcome ideological preferences in generating legislative support. Pork is 
exchanged for votes in multiparty presidential systems like Brazil (Ames 2001; Pereira and Mueller 2004; Alston and Mueller 2006; Alston et al. 2008). As legislators are well aware, this access to budgetary resources increases the likelihood of their political survival (Ames 1987; Samuels 2002; Pereira and Renno 2003).

A second approach - roughly echoing parliamentary theories - has emphasized that coalition goods such as positions in the pro-government coalition and cabinet are strategic resources available to presidents (Martínez-Gallardo 2005). This approach has examined how executives may construct coalitions and cabinets in ways that maximize legislative support, even with weak and undisciplined parties. In brief, executives are more successful in obtaining support when constructing majority cabinets that minimize the presence of non-partisan ministers and that distribute cabinet seats proportionally among coalition members (Amorim Neto 2002, 2006; Negretto 2006). Executives may also redesign the internal structure of the presidency itself, using staffing and organizational reforms in ways that resemble the allocation of ministerial posts (Inácio 2006). These ideas are represented visually in Panel 1B of Figure 1, which summarizes the current state of research on executive-legislative exchange under multiparty Presidentialism. Legislative support is separately a function of coalition goods and pork, and the relationship with pork is reciprocal. This view incorporates more fluid ideology and the need for frequent exchange.

\section{The Case of Brazil}

Brazil represents an ideal case for considering the roles of both pork and coalition goods in executive-legislative exchange. Largely as a consequence of its open-list proportional representation electoral system and its federal structure, Brazil has a highly-fragmented party 
system (Mainwaring 1999) in which pork is very valuable. The reduced importance of ideology is evident in the party-switching behavior of legislators (Melo 2004; Desposato 2006). Extreme multipartism means an executive must exchange robustly with the legislative branch but has many potential partners for doing so. ${ }^{2}$ Further, this exchange must be ongoing. While parties in the pro-presidential coalition frequently vote with the announced position of party leaders in the aggregate (Figueiredo and Limongi 2000), coalition discipline is far from perfect (Ames 2002; Amorim Neto 2002). Brazilian executives must build legislative support almost from scratch with each new controversial proposal (Samuels 2000).

Just as significantly, the institutional tools and resources available to the Brazilian executive are substantial enough to help correct for minority status and party fragmentation (Figueiredo and Limongi 1999; Amorim Neto, Cox, and McCubbins 2003). The Brazilian executive's toolbox is chock-full. Among other strategic resources, the Brazilian executive controls the disbursement of pork to legislators through the execution of individual and collective budgetary amendments and establishes the characteristics of her governing coalition (subject, of course, to certain constraints). The executive establishes the heterogeneity and size of the coalition and determines the proportionality of partisan representation within the cabinet, outcomes we refer to as "coalition goods". Recipients of these goods may enjoy benefits such as

\footnotetext{
${ }^{2}$ Since 1990 the party of the president has always held less than $25 \%$ of the seats in the lower house. In mid-2009 under President Lula this figure stands at $15 \%$.
} 
improved ideological satisfaction, electoral advantages, prestige, enhanced representation, and greater checks on executive power. ${ }^{3}$

\section{The Presidential Toolbox: Integration and Dynamism}

We have two primary objectives in advancing institutional research on executivelegislative exchange in multiparty presidential systems. The first is to consider jointly the influence of pork and coalition goods on legislative support. Executives implement strategies that utilize multiple tools in their toolboxes. We have no reason to believe that either the decision-making processes or the effects of these different tools are independent of one another. Consequently, the current picture of executive-legislative exchange is incomplete. We aim to widen the analytical lens by integrating and merging the "pork" argument and the "coalition goods" argument.

Our second objective is to model dynamism in this system, including temporal factors that shape the relationship between coalition goods and pork. In terms of dynamics, the distribution of coalition goods like cabinet seats precedes the distribution of pork. This temporal precedence creates a disconnection between coalition goods and legislative support. In fact, our data show a relatively small and inverse relationship between the size of a president's coalition

${ }^{3}$ Other reasons for choosing the Brazilian case are pragmatic. Much of the research on executive-legislative exchange in multiparty presidencies has used the Brazilian case, which makes our study a natural extension. Additionally, the data requirements for this type of analysis are considerable. Data on legislative support, pork, coalitions, and cabinets at different time points are all necessary, and these data are available for the Brazilian case. 
(i.e., the number of legislative seats in the lower house) and aggregate legislative support in Brazil. Instead of having a direct influence, we propose that decisions about distributing coalition goods work indirectly on legislative support by shaping the distribution of pork. This temporal ordering and the fluidity of pork lead to different roles for pork and coalition goods. Executives are able to use pork as a fine-tuning tool in generating legislative support, after employing the blunt instrument of distributing coalition goods. To use a nautical metaphor, the baseline distribution of coalition goods charts the initial course that the presidency will follow as it sets the ship of government to sail, while pork acts as the "rudder" that the executive can use to make eventual course corrections along the way.

How, specifically, should we expect these two types of tools to interact? In political systems in which voting outcomes are strongly predicted by ideology, the value of coalition goods exceeds the value of pork. However, when ideology is not an overwhelmingly strong factor, pork and coalition goods should become imperfect substitutes in the political marketplace. Legislators derive substantial positive utility from both types of resources, and the executive takes this substitutability into account in devising legislative strategies. Consequently, we should observe coalition goods being offered as a substitute for pork (and vice versa).

We also believe that popular support for a president influences legislative support indirectly by shaping pork expenditures. The president may rely on popularity to put pressure on or "persuade" the legislature, as in Neustadt's (1960) seminal arguments about a president's professional reputation (i.e., respect among other political elites) and public prestige (i.e., popularity with the public). However, legislators are unlikely to provide their support for free, even when facing a publicly popular executive. Instead, we should expect the price of legislative support to drop as the potential electoral cost of opposing a popular executive increases. As a 
consequence, a more popular president should be able to expend fewer resources to produce a certain level of legislative support. Similarly, we anticipate that an executive's "lame duck" status as he serves out the remainder of a final term leaves the executive with little bargaining leverage. The imminent departure of a president should decrease the effectiveness of pork and require greater expenditures. Both of these variables attempt to gauge how difficult it is for legislators to say "no" to the president: more difficult when the president is riding high in the polls, less so when he is a lame duck.

Another important feature of this dynamic system is that the relationship between pork and legislative support is a reciprocal one. Legislators provide support after receiving pork, while presidents also reward legislators for their support in a post hoc manner (Pereira and Mueller 2004; Alston and Mueller 2006). We intend to model explicitly the dynamics of this reciprocal relationship. Pork expenditures should affect future legislative support, which in turn should affect future pork expenditures. Modeling this reciprocal relationship also requires controlling for momentum in legislative support over time. Even in a relatively weak ideological environment, ideology should contribute to some stability in legislative support. Further, executive distribution of resources (and especially coalition goods) should have effects on legislative support that do not erode immediately. Pork expenditures should exhibit a similar momentum over time. Legislators come to expect a baseline of particularistic monetary benefits as pork distribution becomes bureaucratized and routine. The executive must also use pork to fill an ongoing need for legislative support. 


\section{The Political Context}

We describe a political environment in which legislative voting is unreliable and fragmented but an executive has a number of institutional tools at her disposal to build winning coalitions on an ongoing basis. In such an environment, the political context assumes added importance. For example, does the executive have the option of forging a large coalition based on the distribution of parties and preferences in the legislature? If so, an executive can concentrate on firming up support and discipline within the coalition. If not, an executive likely must direct substantial resources outside the formal coalition to build majorities, as well. As a consequence, while the overall patterns of exchange may stay relatively consistent, the particular tactics used by individual executives may vary based on the environment.

All Brazilian presidents since 1988 have possessed roughly the same institutional tools but have faced different bargaining conditions and have employed different tactics in the pursuit of legislative success. The only instance during this time period without a clear majoritarian coalition was from March 1990 to October 1992 under President Fernando Collor, who governed with ad hoc coalitions and minority support in the Chamber of Deputies (the lower legislative house). Collor's tactical choices proved unsustainable and contributed to his eventual impeachment and removal from office (Weyland 1993).

The first president in our analysis, Fernando Henrique Cardoso (1995-2002), had palatable options for creating large coalitions. ${ }^{4}$ Consequently, he governed in a way that more

\footnotetext{
${ }^{4}$ Cardoso ran for office in 1994 as the popular architect of a successful anti-inflation plan and won the presidency outright in the first round. The 1994 elections were the first concurrent elections for president and Congress since 1950, allowing for significant pre-election
} 
resembled a parliamentary agenda cartel (Amorim Neto, Cox, and McCubbins 2003). After his first year in office, Cardoso's focused center-right coalition included almost $75 \%$ of the Chamber of Deputies. Cardoso rewarded coalition parties with cabinet seats in a highly proportional way (except for his lame-duck final year) and sent a relatively small proportion of pork outside the formal coalition.

The president who followed, Luiz Inácio "Lula" da Silva (2003-present), was in various ways dealt a more difficult hand. Crafting a large, homogeneous coalition would not be possible given the distribution of preferences in the Congress. Even Lula's own leftist Workers' Party (PT) exhibited serious internal fractures, which would be worsened by some of the conservative fiscal policies Lula needed to pursue. These policies would require constitutional amendments and $60 \%$ supermajority voting support in the legislature.

Given the constraints in the environment, substitution between pork and coalition goods would assume extreme importance. Lula would need to firm up interior support with coalition goods and attract support from opponents with pork. Substitution was particularly evident during Lula's first year, when he crafted a relatively proportional and ideologically compact cabinet to induce the support of the coalition parties. He increased dramatically the number of ministerial portfolios and used the new posts to satisfy factions within PT. The cabinet remained proportional because the partner parties held relatively few seats in the Chamber. Simultaneously, Lula sent a large proportion (nearly $76 \%$ in 2003) of the pork outside the formal

coordination of the Cardoso alliance. In a rare feat, Cardoso's own party won the governorship of the three most important states, and parties supporting him made significant gains in Congress. 
coalition as an inducement for his typical ideological opponents. ${ }^{5}$ The substitution pattern would continue after Lula's first year, but in a more limited fashion. Lula's cabinet became much less proportional upon adding the relatively large PMDB to the coalition with little cabinet compensation.

Our proposed relationships are summarized in Panel 1C of Figure 1, which illustrates how our approach simultaneously integrates and moves beyond previous lines of research on legislative support under multiparty presidentialism. In the theoretical model outlined in Panel 1C, coalition goods and an executive's bargaining leverage are major inputs that determine how an executive will use pork to build legislative support.

\section{Data and Methods}

The dataset used in this analysis consists of monthly data for the years 1997-2005, thereby including 72 months in which Fernando Henrique Cardoso served as president and 36 months in which Luiz Inácio Lula da Silva was the Brazilian chief executive. The Appendix provides a summary of variables used in the analysis.

We use three-stage least squares regression (Zellner and Theil 1962) as our method of data analysis. We are dealing with a system of equations with a number of endogenous variables due to both reciprocal causation and endogenous strategic choices on the part of the executive.

\footnotetext{
${ }^{5}$ The budget for 2003 was drafted by the previous administration in 2002 . However, Lula had discretion over whether he would actually disburse the slated earmarks. Therefore, while institutional momentum perhaps explains some of the outward spending, Lula was also explicitly targeting his pork expenditures.
} 
Three-stage least squares treats dependent variables and any other specified endogenous variables as correlated with the disturbances in the system of equations. Remaining variables are considered exogenous and all are used as instruments in first-stage regressions. Three-stage least squares also accounts for variables that are simultaneously determined with dependent variables. These features allow direct mapping from executive decision-making to our empirical specification.

We use four different equations and dependent variables to establish a fuller picture of executive strategy and effects on legislative support, including the importance of bargaining conditions. Three of the equations have dependent variables that appear as independent variables (sometimes lagged) in other equations in the system, which is typical of equations being analyzed with three-stage least squares. The reciprocal relationship between legislative support and pork also necessitates multiple equations as one would see with two-stage least squares, which is a less efficient option than three-stage least squares. Again, while the final-stage specifications are different for each equation, the first-stage regressions all use the same full set of exogenous variables.

The primary dependent variable in this analysis is Legislative support for the executive, which is the average percentage of legislators in the Chamber of Deputies voting with executive positions in a given month. We convert this variable into a proportion and then perform a logistic transformation to make it suitable as a dependent variable in a linear equation. The dependent variable of the second equation is Logged amendment expenditures, or the log of the total individual budget amendments executed for legislators in a given month (i.e., pork). Taking the $\log$ of this variable is driven partly by our belief that pork spending should produce diminishing marginal returns and partly by diagnostic evidence of non-linear effects. The Proportion spent on 
coalition (also logistically transformed for use as a dependent variable) is the proportion of total individual budget amendments expended by the executive on members of pro-presidential coalition parties. Finally, the fourth dependent variable is Amorim Neto's (2002) indicator of Cabinet coalescence, or the overall proportionality between Chamber seat shares and cabinet seat shares for pro-presidential coalition parties. Autocorrelation diagnostics support assertions that these dependent variables are strongly predicted by their previous values. In particular, diagnostics suggest that the variables are subject to $\mathrm{AR}(1)$ processes. A one-month lag of the dependent variable appears in first three equations. ${ }^{6}$

Other goods managed by the executive appear on the right-hand side of the equations. Over the nine years examined in our data the institutional rules remain constant, thus relieving any need to control for rules in the empirical specifications. ${ }^{7}$ Based on surveys of Brazilian legislators, Coalition heterogeneity is calculated as the average Sani-Sartori ideological distance score (Sani and Sartori 1983) of the parties in the coalition, as measured from the president's

\footnotetext{
${ }^{6}$ We do not include a lag for Cabinet coalescence because it is fundamentally a different kind of variable. This variable is largely static with periodic shifts corresponding to cabinet reshuffles. So, while previous values are predictive, the relationship is not a causal one.

7 An exception is Constitutional Amendment No. 16 of June 4, 1997, which allowed one consecutive reelection to executive posts. However, expectation of this reform antedates our time series. Another exception is Constitutional Amendment No. 32 of September 11, 2001, which restricted the president to a single reissue of each lapsed decree. Pereira, Power and Rennó (2008) observe that the effects of this constitutional reform on presidential agenda-setting powers were largely innocuous.
} 
party. The distance score for each party is weighted by the percentage of Chamber seats that it was contributing to the pro-presidential coalition at the time. ${ }^{8}$ We use this measure instead of a blunter measure such as the ideological range of the coalition (i.e., the absolute distance from the leftmost to the rightmost party) because the spread from the executive seems most relevant from the president's point of view. Another potential measure of the distribution of coalition goods is the Effective number of coalition parties, which is $1 / \sum s_{i}^{2}$, where each $s_{i}$ is the proportion of coalition legislative seats held by a particular coalition party in the Chamber of Deputies. This measure better operationalizes costs to the executive than would the raw number of parties in the coalition. Finally, Coalition seats is the number of seats in the Chamber of Deputies held by propresidential coalition parties.

A few other independent variables appear in our system of equations. We operationalize Presidential popularity as the percentage of positive public evaluations of the president minus the percentage of negative evaluations. The dichotomous Lame duck variable takes the value of 1 during the final year of Cardoso's second term. Lula is a dichotomous variable indicating the months during the Lula Administration, while Lula's first year is a dichotomous variable for the first year of Lula's presidency. In addition to being effective instruments, these final two variables also measure differences in bargaining conditions. We want to be sure that particular

\footnotetext{
${ }^{8}$ Party switching is common in Brazil, and interparty migrations mean that coalition size, ideological heterogeneity, and cabinet coalescence undergo minor changes every month even if the partisan composition of the coalition remains constant. Fortunately, we were able to obtain data on individual party switching for every month from 1997 through 2005 and have incorporated these data into the calculation of our other variables.
} 
bargaining conditions are not responsible for driving the overall strategic results, so we control for these differences with the two Lula variables. As previously mentioned, Lula's bargaining context overall diverged significantly from that of Cardoso. Additionally, certain patterns that we have predicted are expected to appear especially strongly during Lula's first year in office. Separating out that first year helps to control for Lula's need for supermajorities and the exaggerated pattern of substitution, thus ensuring that the results are not being driven by a single year in the data.

Figure 2 displays by cabinet the variance in the three most important variables in the system of equations. Despite a high average value, one can see that legislative support varies rather widely throughout the years examined. Furthermore, the pattern of substitution is evident in this figure, as relatively higher values of pork are associated with relatively lower values of cabinet heterogeneity and vice versa. The lame-duck nature of Cardoso's final year (primarily the fourth cabinet) stands out in the figure, as well.

[Figure 2 about here]

\section{Results}

Table 1 displays the results of the three-stage least squares regression. The bottom dependent variable in the table is the proportionality or coalescence of the cabinet. An executive with the luxury of creating a coalition that includes a larger number of seats in the lower house, as was typically the case with Cardoso, can also afford to focus on intra-coalitional rewards like proportional cabinets. Also as anticipated, Lula awarded cabinet seats in a proportional manner during that first year as he combined the inner distribution of coalition goods with the external distribution of pork in pursuit of supermajorities. 
[Table 1 about here]

The second dependent variable from the bottom is the proportion of pork that remains within the coalition. This equation is included in the system due to a belief that it is strongly codetermined with the overall amount of pork; these decisions are linked in the broader executive strategy. As hypothesized, this proportion (logistically transformed) exhibits substantial stability from one month to another. Further, an executive who can feasibly assemble a larger coalition (in terms of seats held in the lower house) is also able to focus more of the pork within the coalition. The raw coalition size is not treated as endogenous in the system because it is subject to significant external constraints - namely the actual partisan distribution in the Chamber of Deputies, which in turn derives from the popular elections held in 1994, 1998, and 2002. The coefficient for Lula's first year does not reach statistical significance in this equation, but this is largely due to its relationship with the other two independent variables. ${ }^{9}$ Again, this variable's inclusion is meant to control for the very strong substitution pattern in Lula's first year.

Pork serves as the dependent variable in the second equation from the top in Table 1. Pork, too, is strongly influenced by its previous value. Also in line with our predictions, pork spending is a function of the previous level of legislative support as executives reward supportive behavior. An executive can convert popularity into a legislative benefit, though the relationship

\footnotetext{
${ }^{9}$ The number of seats held by the coalition in that first year takes on low values in the overall dataset, thus creating collinearity. The lag of the dependent variable is also linked to the Lula's first year variable in that it captures the month-to-month stability in internal pork expenditures in that first year. Lula's first year becomes a highly effective predictor with the removal of either of the other independent variables from the equation.
} 
with legislative support is indirect. Instead, as we had suggested, a more popular executive is able to expend less pork in building legislative support. ${ }^{10}$ The direction on the coefficient for lame duck status defies our expectations, but the reasoning may be the same. We find that Cardoso actually spent less during his lame-duck period, but this lower level of spending may have been an acknowledgement that the pork was going to buy far less. Cardoso may have conceded support and saved some money that final year.

We find evidence of a substitution effect between coalition goods and pork in Brazil. ${ }^{11}$ Executives assembling more ideologically diverse and more proportional cabinets tend to expend less on pork. Our proposal, again, is that a particularistic good like pork also carries substantial value in a country like Brazil, so pork can be used as a substitute for coalition goods. Consequently, an executive can compensate for an ideologically narrower or less proportional cabinet through increased pork expenditures. ${ }^{12}$ Similarly, an executive can get by with expending less pork when the cabinet is ideologically broader or the cabinet is more proportional. Worth noting is that we specify coalition heterogeneity and cabinet coalescence as contemporaneous

\footnotetext{
${ }^{10}$ Presidential popularity does not directly influence legislative support in our data.

${ }^{11}$ We estimate separate equations using Coalition heterogeneity and the Effective number of coalition parties due to a correlation of 0.916 between these two variables. The results for the two specifications are substantively identical.

12 Alternative static analyses using interaction terms support this story of substitutability. Graphic representations of the results show that pork has a greater influence on legislative support when coalition goods are in lower supply, and vice versa. The results of these separate analyses are available from the authors upon request.
} 
with pork expenditures. While the actual distribution of pork follows the distribution of coalition goods, an executive attempts to fine-tune with pork expenditures based on the current state of the coalition. Finally, the different bargaining conditions and policymaking needs encountered by Lula do produce a tactical difference. After controlling for his coalition and cabinet construction, Lula still must spend more than anticipated on pork. We hypothesized that internal factions in Lula's party, the distribution of parties in the Chamber, and other factors added up to a more difficult bargaining environment for Lula and one that necessitated greater resource expenditures. $^{13}$

The final dependent variable is legislative support. As proposed, legislative support is primarily a function of previous legislative support and previous pork distribution. The result with respect to individual amendments (pork) contravenes how some view the role of pork distribution on legislator behavior. For example, Limongi and Figueiredo (2007) claim that establishing a causal relationship between votes and pork is impossible, essentially basing their claim on descriptive evidence in the form of a frequency distribution. However, time-series

13 This system of equations, as specified, does not directly contemplate the effects of the mensalão corruption scandal, which involved illicit payments from the Lula Administration to legislators during the timeframe of early 2004 through May 2005. A dichotomous variable for that time period is not significantly related to any of the dependent variables. Most likely, the difficult bargaining conditions had caught up with Lula, and the illicit payments were necessary for the various other executive resources to maintain a certain level of effectiveness - a relationship beyond the scope of our model. 
analysis here that controls for other factors that may influence legislator voting behavior reveals that appropriation of pork positively increases legislative support in Congress and vice versa.

\section{The Case of Pension Reform}

A brief case from Lula's trying first year illustrates results from Table 1 in an especially clear manner. In particular, the case of the 2003 pension reform (see Alston and Mueller 2006; Melo 2008) demonstrates the interaction between pork and coalition goods, as well as the importance of the bargaining context and goals. Upon assuming office, Lula needed to implement fiscally conservative policies to calm international lenders and markets and to ease budgetary pressures inside the country. Success, however, meant overcoming his strong leftist history, a severely fractured party, and rather limited ideological support in the Congress. Many of the necessary measures would require constitutional amendments and a concomitant $60 \%$ support in the Congress. Even with highly disciplined parties (which these were not), Lula's baseline support would be insufficient. Lula found himself needing to build supermajorities by combining partisan opponents and more leftist legislators who would dislike the policy program.

The relative ideological fluidity in Brazil could cut both ways. Some rightist partisan opponents would vote against Lula's reforms despite ideological agreement with them, while leftist legislators could be brought along with the proper inducements. The game would be much more difficult to solve than if ideology played the determinative role in voting decisions, but it was also possible for Lula to build the supermajorities he required - a virtual impossibility in the world of disciplined parties and responsible party government.

The Lula government, like the previous Cardoso government, proposed the taxation of retired worker pensions as a key component of solving the fiscal crisis of the Brazilian 
government. The pension legislation represented an extreme departure from previous Lula and PT rhetoric, which had derided any attempts at pension reform as "neoliberal" and "technocratic," and this volte-face created serious fissures within the party and the broader governing coalition. The proposal also antagonized many of the President's most important support groups like labor unions and civil servants.

In the face of a difficult bargaining environment, Lula's substitution behavior was an accentuated version of the pattern identified in Table 1. As mentioned earlier, Lula assembled a relatively narrow coalition and proportional cabinet to induce internal support while buying support from outside the coalition with pork. As shown in Table 2, Lula's strategy produced the desired result with 74\% support for the pension reforms in the Chamber of Deputies, despite only 213 votes (about 42\%) from within the coalition. Even strong partisan opponents like the centrist PSDB and the conservative PFL (the two principal parties of the former Cardoso coalition) largely went along with the initiative. Helping Lula even more than the ideological acceptability of the legislation was likely the fact that nearly $41 \%$ of the overall pork was disbursed to individuals associated with PSDB and PFL alone in 2003. Similarly, about $89 \%$ of the pork disbursed at the state level in 2003 went to states governed by non-coalition parties, with about $34 \%$ of the total going to states governed by PSDB or PFL. Thus, pork helped Lula - an inexperienced formateur - get through his difficult first year in 2003. Only in 2004, with the incorporation of the PMDB, did Lula's coalition begin to resemble its current supermajoritarian form.

[Table 2 about here] 


\section{Summary and Discussion}

Traditional theories of government formation and policymaking describe a tidy parliamentary world in which strong and disciplined parties vote based on political ideology. We have examined executive-legislative exchange when such conditions are absent. As in many other separation-of-powers systems, the political parties of Brazil are relatively weak and undisciplined, and political ideology is far from a deterministic force. In short, a different set of rules applies.

Figure 1 shows how our theoretical approach differs from its predecessors. Traditional parliamentary models assume unambiguous exchange of coalition status and cabinet seats for legislative votes. This is predominantly a one-way relationship. When sufficient legislative support is no longer forthcoming, a government reformation or new election creates a new start point.

Multiparty presidential regimes, for historical and institutional reasons, frequently do not enjoy strong and disciplined parties and cannot simply reshuffle the deck with new elections. Hence, studies of these regimes have looked separately at ways for executives to use particularistic goods like pork to build support or ways for executives to boost voting with coalition goods.

By merging previous literatures on cabinet formation and distributive politics, our work has set the stage for a more integrated and refined view of executive-legislative exchange in multiparty presidential regimes. Executive strategies for using coalition goods and pork are not independent, nor are their effects on legislative support. The empirical evidence supports our proposal that an executive uses particularistic goods like pork to fine-tune legislative support after doling out longer-lasting coalition goods and gauging bargaining leverage based on factors 
like popular support or lame-duck status. While pork is often an effective complement to coalition goods, institutional arrangements may also allow pork to serve as a substitute in building legislative support. Such substitution may be particularly attractive if an executive needs to obtain support from partisan or ideological foes. Pork is also flexible enough to permit ongoing adjustments as it interacts reciprocally with legislative support.

Executives of coalitional presidencies often operate in dynamic and conditional environments. We have identified broad strategic patterns in executive-legislative exchange, but our comparison of specific Brazilian presidencies and the pension reforms example also reveal that executives may find different tactics for implementing these strategies. These tactics respond to the particular goals of the president and the characteristics (institutional and otherwise) of the bargaining environment. In our example, Lula faced a need for supermajority support with a minority of fragmented natural allies in the legislature. In response to this situation, Lula pointedly used coalition goods to firm up support among these allies and sent pork to partisan opponents as a substitute. The contrasting experiences of Cardoso and Lula show that presidents draw on what we have called the "executive toolbox" in different ways, responding in each case to contextual and temporal factors.

The part ideology plays in this drama is not a straightforward one. Ideological agreement does not automatically imply legislative support, nor is ideological disagreement a certain portent of legislative opposition. Instead, ideology becomes a variable in a complex set of calculations. Given the circumstances, how much does ideological agreement decrease the cost of support? Similarly, what is the cost of overcoming ideological disagreement?

We have joined in a research agenda that examines how institutional arrangements overcome party fractionalization and the need for coalitions under multiparty presidentialism. 
Democratic equilibria frequently emerge, but surmounting the obstacles is not easy. From the executive's point of view, multiparty presidentialism is not a very user-friendly format. In addition to acquiring the managerial skills necessary for public policy, presidents must also learn to become effective wranglers of interparty alliances and must master the strategic, interdependent use of multiple resources. We have begun to understand how presidents can (or cannot) achieve all this, but examinations of other multiparty systems are likely to yield significant insights. Even among the subset of cases with high levels of party fragmentation, the constitutional and partisan powers of presidents vary considerably (Shugart and Carey 1992). As Altman (2000) notes, the diversity among multiparty presidential systems argues strongly for examining theories on a rigorous country-by-country basis. 


\section{Figures and Tables}

Table 1. Three-Stage Least Squares Regression

\begin{tabular}{|c|c|c|c|}
\hline Variable & Coefficient & Std. Error & $\mathrm{p} \leq$ \\
\hline \multicolumn{4}{|l|}{ DV: Logistically transformed legislative support } \\
\hline Logistically transformed legislative support $(\mathrm{t}-1)$ & 0.531 & 0.081 & 0.001 \\
\hline Logged amendment expenditures ( $t-1)$ & 0.096 & 0.039 & 0.014 \\
\hline Constant & -1.526 & 0.833 & 0.067 \\
\hline \multicolumn{4}{|l|}{ DV: Logged amendment expenditures (t-1) } \\
\hline Logged amendment expenditures ( $t-2)$ & 0.305 & 0.081 & 0.001 \\
\hline Logistically transformed legislative support ( $\mathrm{t}-2)$ & 0.275 & 0.108 & 0.011 \\
\hline Coalition heterogeneity $(t-1)$ & -43.227 & 8.555 & 0.001 \\
\hline Cabinet coalescence $(\mathrm{t}-1)$ & -0.068 & 0.028 & 0.014 \\
\hline Presidential popularity (t-1) & -0.067 & 0.012 & 0.001 \\
\hline Lame duck (t-1) & -4.020 & 0.810 & 0.001 \\
\hline Lula presidency $(\mathrm{t}-1)$ & 1.987 & 0.488 & 0.001 \\
\hline Constant & 24.510 & 2.593 & 0.001 \\
\hline \multicolumn{4}{|l|}{$\begin{array}{l}\text { DV: Logistically transformed proportion of pork } \\
\text { within coalition }(t-1)\end{array}$} \\
\hline Logistically transformed proportion $(\mathrm{t}-2)$ & 0.766 & 0.389 & 0.001 \\
\hline Coalition seats ( $\mathrm{t}-1)$ & 0.004 & 0.001 & 0.001 \\
\hline Lula's first year (t-1) & -0.262 & 0.201 & 0.193 \\
\hline Constant & -1.066 & 0.409 & 0.009 \\
\hline \multicolumn{4}{|l|}{ DV: Cabinet coalescence $(\mathrm{t}-1)$} \\
\hline Coalition seats $(t-1)$ & 0.125 & 0.011 & 0.001 \\
\hline Lula's first year ( $\mathrm{t}-1)$ & 20.236 & 1.945 & 0.001 \\
\hline Constant & 12.257 & 4.008 & 0.002 \\
\hline
\end{tabular}

NOTES: In addition to the three dependent variables, Coalition heterogeneity ( $t-1)$ is considered endogenous. The sample size is 104 months, with 4 months excluded due to the 1-month and 2-month lags at the start of the time series and at the start of the Lula presidency (since lagged values are not allowed to cross from one presidency to another). $\mathrm{R}^{2}$ for the four equations, in order, is $0.420,0.787,0.845$, and 0.577 . However, these values cannot be interpreted normally due to the non-nesting that results from using instruments to estimate parameters. All tests are two tailed. 
Table 2. Roll Call Votes on Social Security Reform by Political Party (Aug. 2003)

\begin{tabular}{lrrr}
\hline \hline Party & \multicolumn{1}{c}{ Yes } & No & Total \\
\hline PCdoB & $7(64 \%)$ & $4(36 \%)$ & 11 \\
PDT & $6(50 \%)$ & $6(50 \%)$ & 12 \\
PL & $39(100 \%)$ & $0(0 \%)$ & 39 \\
PPS & $17(100 \%)$ & $0(0 \%)$ & 17 \\
PSB & $18(90 \%)$ & $2(10 \%)$ & 20 \\
PT & $80(95 \%)$ & $4(5 \%)$ & $84 *$ \\
PTB & $42(84 \%)$ & $8(16 \%)$ & 50 \\
PV & $4(80 \%)$ & $1(20 \%)$ & 5 \\
\hline PFL & $32(48 \%)$ & $34(52 \%)$ & 66 \\
PMDB & $49(72 \%)$ & $19(28 \%)$ & 68 \\
PMN & $1(100 \%)$ & $0(0 \%)$ & 1 \\
PP & $32(70 \%)$ & $14(30 \%)$ & 46 \\
PRONA & $0(0 \%)$ & $6(100 \%)$ & 6 \\
PSC & $1(100 \%)$ & $0(0 \%)$ & 1 \\
PSDB & $28(53 \%)$ & $25(47 \%)$ & 53 \\
PSL & $1(100 \%)$ & $0(0 \%)$ & 1 \\
\hline
\end{tabular}

Totals $357(74 \%)$ $123(26 \%)$ 480

NOTES: Pro-government coalition parties are PCdoB through PV. Among the remaining group, the PSDB and PFL were explicitly in opposition to the Lula government at the time, with the remaining parties adopting an ambivalent stance. The government's position for the roll call was "Yes."

* Seven PT members also abstained from voting. 


\section{Figure 1. Views of Executive-Legislative Exchange}

1A. Traditional

Parliamentary

Legislative

support

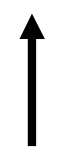

Coalition inclusion \& cabinet positions

NOTE: This view assume that parties are disciplined and that ideology is the primary voting influence. When legislative support no longer proceeds directly from coalition status and cabinet positions, the government is reformed or replaced.
1B. Multiparty Presidential

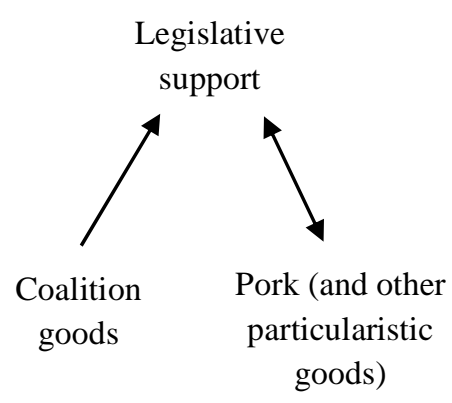

NOTE: This view incorporates more fluid ideology and the need for frequent exchange.
1C. Refined Multiparty Presidential

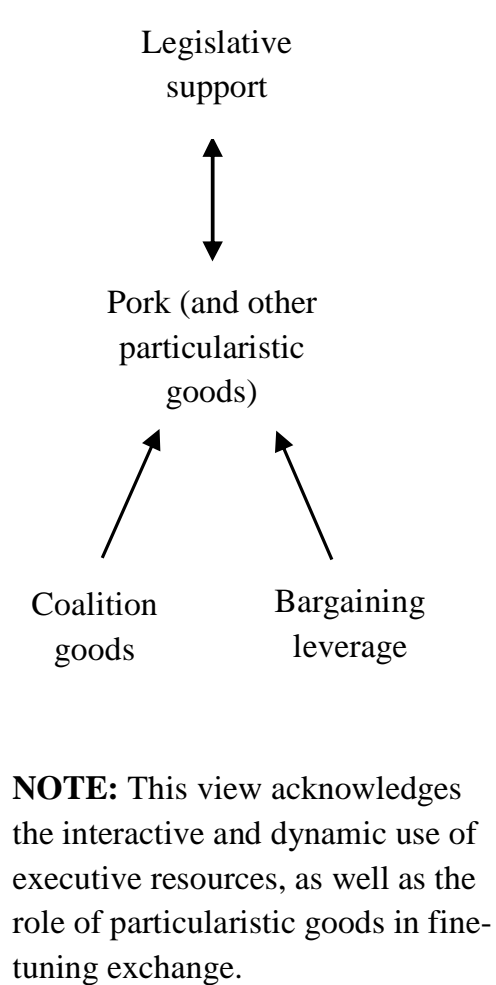


Figure 2. Support, Pork, and Coalitions

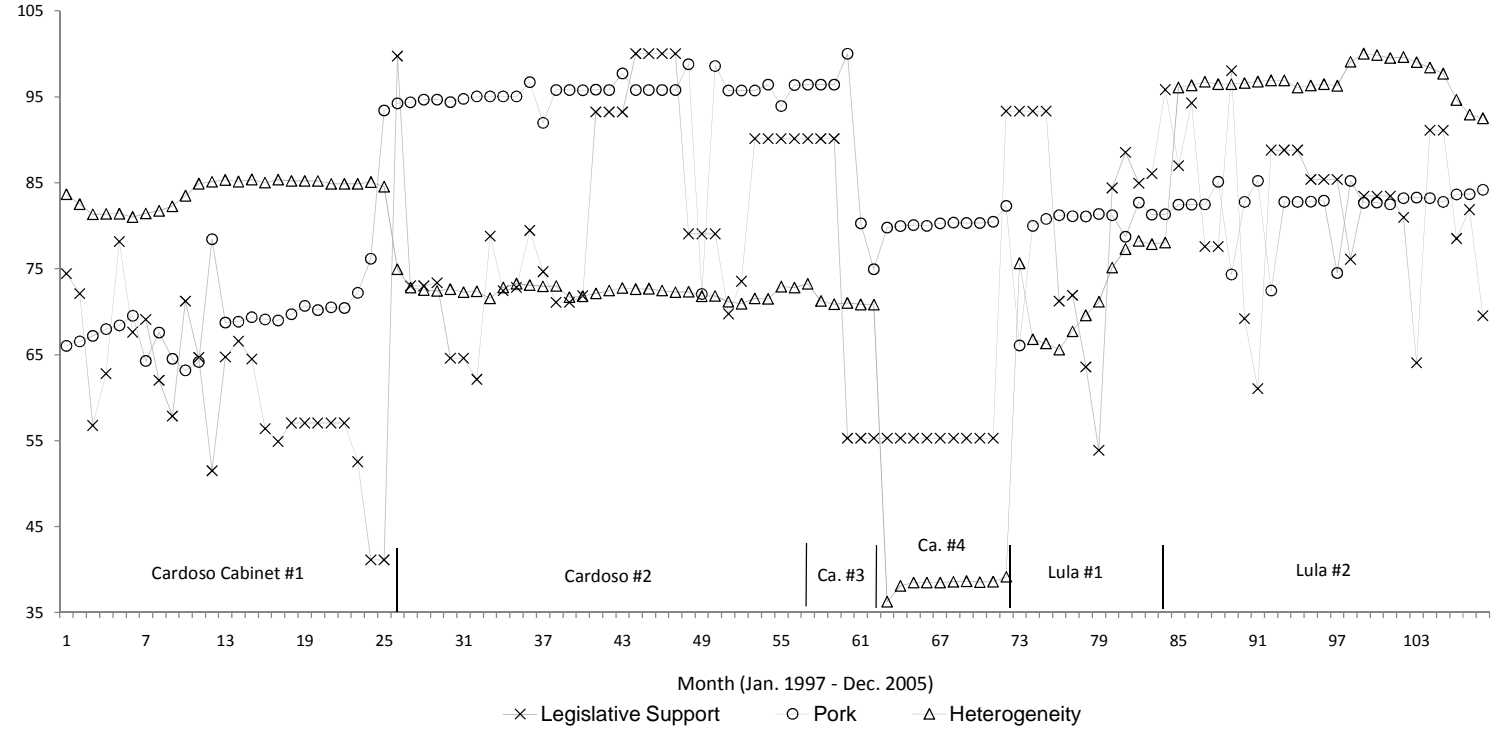
NOTES: The vertical axis is the percent of the maximum observed value for each variable. This graph uses the raw measure of legislative support and the logged
version of pork expenditures. 


\section{References}

Alston, Lee J., and Bernardo Mueller. 2006. "Pork for Policy: Executive and Legislative Exchange in Brazil." Journal of Law, Economics, \& Organization 22 (1): 87-114.

Alston, Lee, Marcus Melo, Bernardo Mueller, and Carlos Pereira. 2008. "On the Road to Good Governance: Recovering from Economic and Political Shocks in Brazil.” In Policymaking in Latin America: How Politics Shapes Policies, eds. Ernesto Stein, Mariano Tommasi, Carlos Scartascini, and Pablo Spiller. Cambridge, MA: Harvard University Press, 111-53.

Altman, David. 2000. "The Politics of Coalition Formation and Survival in Multiparty Presidential Democracies: The Case of Uruguay, 1989-1999." Party Politics 6 (3): 259-83. Ames, Barry. 1987. Political Survival: Politicians and Public Policy in Latin America. Berkeley: University of California Press.

Ames, Barry. 2001. The Deadlock of Democracy in Brazil. Ann Arbor: University of Michigan Press.

Ames, Barry. 2002. "Party Discipline in the Chamber of Deputies." In Legislative Politics in Latin America, eds. Scott Morgenstern and Benito Nacif. New York: Cambridge University Press, 185-221.

Amorim Neto, Octavio. 2002. "Presidential Cabinets, Electoral Cycles, and Coalition Discipline in Brazil.” In Legislative Politics in Latin America, eds. Scott Morgenstern and Benito Nacif. Cambridge: Cambridge University Press, 48-78.

Amorim Neto, Octavio. 2006. “The Presidential Calculus: Executive Policy Making and Cabinet Formation in the Americas." Comparative Political Studies 39 (4): 415-40.

Amorim Neto, Octavio, Gary W. Cox, and Mathew D. McCubbins. 2003. "Agenda Power in Brazil’s Câmara dos Deputados, 1989-98." World Politics 55 (4): 550-78. 
Ansolabehere, Stephen, James M. Snyder, Jr., Aaron B. Strauss, and Michael M. Ting. 2005. "Voting Weights and Formateur Advantages in the Formation of Coalition Governments." American Journal of Political Science 49 (3): 550-63.

Axelrod, Robert. 1970. Conflict of Interest: A Theory of Divergent Goals with Applications to Politics. Chicago: Markham Publishing Co.

Baron, David P., and John Ferejohn. 1987. "Bargaining and Agenda Formation in Legislatures." American Economic Review 77 (2): 303-09.

Baron, David P., and John A. Ferejohn. 1989. "Bargaining in Legislatures.” American Political Science Review 83 (4): 1181-1206.

Cheibub, José Antonio. 2007. Presidentialism, Parliamentarism, and Democracy. Cambridge: Cambridge University Press.

Cheibub, José Antonio, Adam Przeworski, and Sebastian M. Saiegh. 2004. "Government Coalitions and Legislative Success under Presidentialism and Parliamentarism.” British Journal of Political Science 34: 565-87.

de Swaan, Abram. 1973. Coalition Theories and Government Formation. Amsterdam: Elsevier.

Desposato, Scott W. 2006. "Parties for Rent? Ambition, Ideology, and Party Switching in Brazil's Chamber of Deputies.” American Journal of Political Science 50 (1): 62-80.

Figueiredo, Argelina, and Fernando Limongi. 1999. Executivo e legislativo na nova ordem constitucional. São Paulo: Editora Fundação Getúlio Vargas.

Figueiredo, Argelina Cheibub, and Fernando Limongi. 2000. "Presidential Power, Legislative Organization, and Party Behavior in Brazil.” Comparative Politics 32 (2): 151-70.

Groseclose, Tim, and James M. Snyder, Jr. 1996. "Buying Supermajorities.” American Political Science Review 90 (2): 303-15. 
Inácio, Magna. 2006. "Entre presidir e coordenar: presidência e gabinetes multipartidários no Brasil." Paper presented at the III Congress of the Latin American Political Science Association (ALACIP), Campinas, Brazil, September 4-6.

Laver, Michael. 1998. "Models of Government Formation.” Annual Review of Political Science 1: $1-25$.

Limongi, Fernando, and Argelina C. Figueiredo. 2007. "The Budget Process and Legislative Behavior: Individual Amendments, Support for the Executive, and Government Programs." World Political Science Review 3 (3): 1-34.

Linz, Juan J. 1994. "Presidential or Parliamentary Democracy: Does It Make a Difference?” In The Failure of Presidential Democracy: The Case of Latin America, eds. Juan J. Linz and Arturo Valenzuela. Baltimore: Johns Hopkins University Press, 3-87.

Mainwaring, Scott. 1993. "Presidentialism, Multipartism, and Democracy: The Difficult Combination." Comparative Political Studies 26 (2): 198-228.

Mainwaring, Scott. 1999. Rethinking Party Systems in the Third Wave of Democratization: The Case of Brazil. Palo Alto, CA: Stanford University Press.

Martin, Lanny W., and Randolph T. Stevenson. 2001. "Government Formation in Parliamentary Democracies.” American Journal of Political Science 45 (1): 33-50.

Martínez-Gallardo, Cecilia. 2005. "Presidents, Posts, and Policy: Ministerial Appointments and Political Strategy in Presidential Regimes.” Ph.D. dissertation, Columbia University.

Melo, Carlos Ranulfo. 2004. Retirando as cadeiras do lugar: migração partidária na Câmara dos Deputados (1985-2002). Belo Horizonte: Editora UFMG. 
Melo, Marcus André. 2008. "Unexpected Successes, Unanticipated Failures: Social Policy from Cardoso to Lula.” In Democratic Brazil Revisited, eds. Peter R. Kingstone and Timothy J. Powers. Pittsburgh: University of Pittsburgh Press, 161-84.

Montero, Maria. 2003. "Proportional Payoffs in a Model of Two-Stage Bargaining with Reversible Coalitions.” Unpublished manuscript.

Morelli, Massimo. 1999. "Demand Competition and Policy Compromise in Legislative Bargaining.” American Political Science Review 93 (4): 809-20.

Morelli, Massimo, and Maria Montero. 2003. "The Demand Bargaining Set: General Characterization and Application to Majority Games." Games and Econometric Behavior 42 (1): 137-55.

Negretto, Gabriel L. 2006. "Minority Presidents and Democratic Performance in Latin America." Latin American Politics and Society 48 (3): 63-92.

Neustadt, Richard E. 1960. Presidential Power: The Politics of Leadership. New York: John Wiley \& Sons, Inc.

Pereira, Carlos, and Bernardo Mueller. 2004. "The Cost of Governing: Strategic Behavior of the President and Legislators in Brazil's Budgetary Process." Comparative Political Studies 37 (7): 781-815.

Pereira, Carlos, Timothy J. Power, and Lucio R. Rennó. 2008. “Agenda Power, Executive Decree Authority, and the Mixed Results of Reform in the Brazilian Congress.” Legislative Studies Quarterly 33 (1): 5-33.

Pereira, Carlos, and Lucio Renno. 2003. "Successful Re-election Strategies in Brazil: The Electoral Impact of Distinct Institutional Incentives.” Electoral Studies 22: 425-48. 
Samuels, David J. 2000. “The Gubernatorial Coattails Effect: Federalism and Congressional Elections in Brazil.” Journal of Politics 62 (1): 240-53.

Samuels, David J. 2002. "Pork Barreling is Not Credit Claiming or Advertising: Campaign Finance and the Sources of the Personal Vote in Brazil." Journal of Politics 64 (3): 845-63. Sani, Giacomo, and Giovanni Sartori. 1983. "Polarization, Fragmentation, and Competition in Western Democracies.” In Western European Party Systems: Continuity and Change, eds. Hans Daalder and Peter Mair. London: Sage Publications, 307-40.

Shugart, Matthew Soberg, and John M. Carey. 1992. Presidents and Assemblies: Constitutional Design and Electoral Dynamics. Cambridge: Cambridge University Press.

Snyder, James M. Jr., Michael M. Ting, and Stephen Ansolabehere. 2005. "Legislative Bargaining under Weighted Voting." American Economic Review 95 (4): 981-1004.

Stepan, Alfred, and Cindy Skach. 1993. "Constitutional Frameworks and Democratic Consolidation: Parliamentarianism versus Presidentialism.” World Politics 46 (1): 1-22.

Tsebelis, George. 2002. Veto Players: How Political Institutions Work. Princeton: Princeton University Press.

Weyland, Kurt. 1993. "The Rise and Fall of President Collor and Its Impact on Brazilian Democracy." Journal of Interamerican Studies and World Affairs 35 (1): 1-37.

Zellner, Arnold, and H. Theil. 1962. "Three-Stage Least Squares: Simultaneous Estimation of Simultaneous Equations.” Econometrica 30 (1): 54-78. 


\section{Appendix}

Summary of Variables Used in Analysis $(n=104)$

\begin{tabular}{|c|c|c|c|c|}
\hline Variable & Description & Mean & S.D. & Range \\
\hline $\begin{array}{l}\text { Legislative support } \\
\text { (before logistic } \\
\text { transformation) }\end{array}$ & $\begin{array}{l}\text { Average proportion of legislators in Chamber of } \\
\text { Deputies supporting executive positions on } \\
\text { legislative votes in a given month }\end{array}$ & 0.735 & 0.150 & 0.409 to 0.995 \\
\hline $\begin{array}{l}\text { Logged amendment } \\
\text { expenditures }\end{array}$ & $\begin{array}{l}\text { Natural log of total individual budget amendments } \\
\text { executed in a given month for disbursement that } \\
\text { calendar year or the next }\end{array}$ & 22.243 & 2.730 & $\begin{array}{l}16.832 \text { to } \\
26.651\end{array}$ \\
\hline Coalition heterogeneity & $\begin{array}{l}\text { Weighted average of Sani-Sartori ideological } \\
\text { distances for pro-presidential coalition parties from } \\
\text { the median of the executive's party, adjusted for } \\
\text { party switching }\end{array}$ & 0.128 & 0.027 & $\begin{array}{l}0.060 \text { to } \\
0.165\end{array}$ \\
\hline $\begin{array}{l}\text { Effective number of } \\
\text { coalition parties }\end{array}$ & $\begin{array}{l}1 / \sum s_{i}^{2} \text {, where } s_{i} \text { is the proportion of coalition } \\
\text { Chamber seats held by each particular party, } \\
\text { adjusted for party switching }\end{array}$ & 4.394 & 0.787 & $\begin{array}{l}2.809 \text { to } \\
5.820\end{array}$ \\
\hline Cabinet coalescence & $\begin{array}{l}\text { Correspondence between Chamber seat shares and } \\
\text { cabinet seat shares for cabinet parties (as a \%) }\end{array}$ & 56.462 & 8.047 & $\begin{array}{l}37.000 \text { to } \\
70.000\end{array}$ \\
\hline $\begin{array}{l}\text { Proportion spent on } \\
\text { coalition (before logistic } \\
\text { transformation) }\end{array}$ & $\begin{array}{l}\text { Proportion of total individual budget amendment } \\
\text { expenditures spent on coalition party members }\end{array}$ & 0.626 & 0.232 & $\begin{array}{l}0.071 \text { to } \\
0.981\end{array}$ \\
\hline Coalition seats & $\begin{array}{l}\text { Number of seats in the Chamber of Deputies held } \\
\text { by pro-presidential coalition parties (out of } 513 \\
\text { possible), adjusted for party switching }\end{array}$ & 339.642 & 53.051 & $\begin{array}{l}230.892 \text { to } \\
402.400\end{array}$ \\
\hline Presidential popularity & $\begin{array}{l}\text { Percentage of positive public evaluations of the } \\
\text { president minus percentage of negative evaluations }\end{array}$ & 2.733 & 21.678 & $\begin{array}{l}-45.000 \text { to } \\
38.689\end{array}$ \\
\hline
\end{tabular}

NOTES: These values eliminate observations for the first and second months of each president's administration. Allowing the lagged variables to cross administrations is theoretically suspect.

SOURCES: Raw data on legislative support and the effective number of coalition parties came from the Secretary of the Directing Table (Speaker of the House) of Brazil's Chamber of Deputies. The source of the budgetary data was the Controladoria de Orçamentos, Fiscalização e Controle do Senado Federal in Brazil. Our versions of these variables required additional calculations. The coalition heterogeneity variable was constructed using elite surveys of Congress in 1997, 2001, and 2005 in which legislators were asked to place all other parties on a left-right (1-10) scale. We utilized three sources in constructing the presidential popularity variable - DataFolha, Vox Populi, and CNI/Ibope. Missing values were interpolated to create a full monthly time series of presidential popularity data, and we checked inter-source reliability by performing correlational analysis of the interpolated time series. 